\title{
Progression of COVID-19 in a Patient on Anti-CD20 Antibody Treatment: Case Report and Literature Review
}

\author{
Sebastian Burgener, ${ }^{1}$ Philippe Rochat, ${ }^{1}$ Günter Dollenmaier, ${ }^{2}$ Gabriel Benz, ${ }^{3}$ \\ Andreas D. Kistler, ${ }^{1}$ and Rosamaria Fulchini $\mathbb{D I}^{4}$ \\ ${ }^{1}$ Department of Internal Medicine, Cantonal Hospital Frauenfeld, Frauenfeld, Switzerland \\ ${ }^{2}$ Center for Laboratory Medicine, St. Gallen, Switzerland \\ ${ }^{3}$ Center for Sleep Medicine, Department of Pneumology and Sleep Medicine, Cantonal Hospital St. Gallen, St. Gallen, Switzerland \\ ${ }^{4}$ Department of Internal Medicine, Infectious Diseases and Hospital Epidemiology, Cantonal Hospital Münsterlingen, \\ Münsterlingen, Switzerland \\ Correspondence should be addressed to Rosamaria Fulchini; rosamaria.fulchini@stgag.ch
}

Received 21 October 2021; Accepted 28 January 2022; Published 25 February 2022

Academic Editor: Janak Koirala

Copyright ( 2022 Sebastian Burgener et al. This is an open access article distributed under the Creative Commons Attribution License, which permits unrestricted use, distribution, and reproduction in any medium, provided the original work is properly cited.

\begin{abstract}
Accumulating evidence suggests that anti-CD20 treatments are associated with a more severe course of COVID-19. We present the case of a 72-year-old woman treated with the B-cell-depleting anti-CD20 antibody rituximab for seropositive rheumatoid arthritis with severe acute respiratory syndrome coronavirus 2 (SARS-CoV-2) infection causing a clinical relapse more than 4 weeks after the first manifestation. Persistently positive reverse transcription polymerase chain reaction (RT-PCR) results along with a drop in cycling threshold (Ct) values, in addition to recovery of identical viral genotype by whole genome sequencing (WGS) during the disease course, argued against reinfection. No seroconversion was noted, as expected on anti-CD20 treatment. Several other case reports have highlighted potentially fatal courses of COVID-19 associated with B-cell-depleting treatments.
\end{abstract}

\section{Introduction}

Immunocompromised patients are at risk for severe disease courses of COVID-19 and prolonged viral shedding [1]. At the beginning of the pandemic, little was known about COVID-19 patients on anti-CD20 antibody treatment like rituximab, causing prolonged B-cell depletion. However, there is now growing evidence that rituximab is associated with adverse outcomes of COVID-19 infection [2]. Here, we report the intriguing case of a 72-year-old woman receiving rituximab for seropositive rheumatoid arthritis, who experienced a relapsing course of COVID-19. We performed a literature search for case descriptions, including patients with COVID-19 on anti-CD20 antibody treatment.

\section{Case Presentation}

A 72-year-old woman was tested positive for SARS-CoV-2 by RT-PCR in a nasopharyngeal swab on the $4^{\text {th }}$ of February
2021. Her past medical history was remarkable for seropositive rheumatoid arthritis and connective tissue diseaseassociated interstitial lung disease, for which she received rituximab treatment biannually. Five months before COVID-19 onset, she had received her last dose. Other comorbidities included pulmonary arterial hypertension, coronary artery disease, and atrial fibrillation. At the early stage of the national vaccination campaign, our patient had not been vaccinated. Twelve days later, she was hospitalized in another hospital due to respiratory failure. In addition to the known interstitial lung disease, chest computed tomography revealed new bilateral ground glass opacities consistent with COVID-19 infiltrates. The patient received supplemental oxygen, dexamethasone, and a 10-day course of remdesivir. Following her gradual improvement, a nasopharyngeal SARS-CoV-2 antigen test turned out negative on day 22 and follow-up Ct values of RT-PCR were increasing; thus, isolation precautions were stopped. On day 27, the patient was discharged to inpatient pulmonary 
TABle 1: Timeline of clinical and laboratory data during hospitalisation.

\begin{tabular}{|c|c|c|c|c|}
\hline Days after symptom onset & $\begin{array}{c}\text { Day of admission to the other } \\
\text { hospital, day } 12\end{array}$ & $\begin{array}{c}\text { Day of discharge from the } \\
\text { other hospital, day } 25\end{array}$ & $\begin{array}{c}\text { Day of admission to our } \\
\text { hospital, day } 33\end{array}$ & $\begin{array}{c}\text { Day of death, } \\
\text { day } 35\end{array}$ \\
\hline $\begin{array}{l}\text { SARS-CoV-2 PCR } \\
\text { (nasopharyngeal swab) }\end{array}$ & Positive & Positive & Positive & Positive \\
\hline Ct value & 23.0 & 31.4 & 18.2 & 15.2 \\
\hline Heart rate (beats/min) & 95 & 65 & 126 & 135 \\
\hline Blood pressure $(\mathrm{mmHg})$ & $137 / 87$ & $183 / 89$ & $124 / 80$ & $179 / 83$ \\
\hline Fever $\left({ }^{\circ} \mathrm{C}\right)$ & 36.6 & 36.4 & 38.1 & 38.2 \\
\hline Breathing rate (breaths/min) & 20 & 23 & 25 & 32 \\
\hline $\mathrm{SpO}_{2}(\%)$ & 99 & 94 & 100 & 89 \\
\hline $\mathrm{FiO}_{2}(\%)$ & 25 & 21 & 80 & 80 \\
\hline $\begin{array}{l}\text { White blood cell count } \\
\left(\mathrm{x} 10^{9} / 1\right)\end{array}$ & 5.5 & 19.2 & 17.2 & 14.4 \\
\hline C-reactive protein (mg/l) & 152 & 5 & 220 & 224 \\
\hline Ferritin $(\mathrm{mcg} / \mathrm{l})$ & & & & 3446 \\
\hline D-dimer $(\mathrm{mg} / \mathrm{l})$ & & & & 3.22 \\
\hline Lactate dehydrogenase (U/I) & 550 & & & 793 \\
\hline
\end{tabular}

rehabilitation. Thirty-three days after diagnosis, she was admitted to our hospital because of relapsing dyspnea, productive cough, and fever, along with respiratory failure requiring nasal high-flow oxygen therapy and intensive care monitoring. Differential diagnoses included bacterial pneumonia, reinfection with a SARS-CoV-2 mutant, or a relapse of preexisting COVID-19. Inflammatory markers were again elevated, and a computed tomography scan was unchanged (Table 1).

We started treatment with broad-spectrum antibiotics, but sputum analysis and Legionella antigen in the urine were negative. Further invasive measures like mechanical ventilation were not pursued, according to the patient's wishes. 35 days after the first positive RT-PCR test, the patient died from worsening respiratory failure. Autopsy revealed acute diffuse alveolar damage with hyaline membranes due to COVID-19 in addition to underlying interstitial lung fibrosis.

Follow-up of Ct values of RT-PCR during the second course of disease showed a clear drop, which was indicative of a recurrence of previous COVID-19 (Figure 1).

To rule out reinfection by a mutant, we performed whole genome sequencing of SARS-CoV-2 of the first and last nasopharyngeal swab isolates (days 0 and 35 , respectively). Viral genotypes showed identical sequence patterns, and mutational analysis for $\mathrm{N} 501 \mathrm{Y}$ and $\mathrm{E} 484 \mathrm{~K}$ was negative. Furthermore, SARS-CoV-2 serology was not able to detect IgG or IgM antibodies. These findings led to the conclusion that our patients' clinical deterioration was due to a prolonged and relapsing course of COVID-19.

\section{Discussion}

Our literature review showed accumulating evidence for variable clinical courses of COVID-19 in patients with functional B-cell immunodeficiency due to treatment with rituximab (Table 2 ).

Reported patients mostly suffered from hemato-oncological or rheumatological comorbidities as an indication for rituximab treatment. Prolonged shedding of
SARS-CoV-2 in nasopharyngeal swabs along with either a benign or adverse outcome is a notable feature, independent of the underlying disease. To our knowledge, only one case report has provided whole genome sequencing to rule out reinfection during a prolonged clinical course [2]. This was an important differential diagnosis in our case, since our patient's clinical worsening occurred during the epidemiological situation of a nationwide third wave of COVID-19 with upcoming variants of concern. The substantial drop in $\mathrm{Ct}$ values during the second course of disease could not be explained by preanalytical sampling differences [18], and reinfection was ruled out by genetically identical viral variants of the first and last isolate. A possible hypothesis explaining the initial decrease in viral load, based on in vitro data but not confirmed by clinical studies [19, 20], could be that remdesivir reduced viral replication, but after stopping antiviral treatment, viral clearing was not possible due to an insufficient antibody response and reemerging viral replication led to a clinical relapse. The potentially severe COVID-19 course under rituximab suggests that, in addition to cellular immunity, humoral immunity plays an important role. Therefore, monitoring of immunocompromised patients with B-cell depletion after stopping antiviral treatment is crucial, and repeat quantitative RT-PCR, in addition to clinical assessment, might be useful to detect re-emerging viral replication and infectivity.

Our single case description may not be generalizable to other immunocompromised populations. However, cases with relapsing and prolonged courses have been attributed to reduced viral clearance due to the lack of anti-SARS-CoV2 antibody production by prolonged B-cell depletion after anti-CD20 therapy, as was the case in our patient $[3,5,7,10,17]$.

This case also highlights the infection control challenges in the handling of this special population with persistent shedding of potentially viable virus.

In conclusion, caution should be taken in patients with anti-CD20 antibody treatment, as they can acquire SARS- 


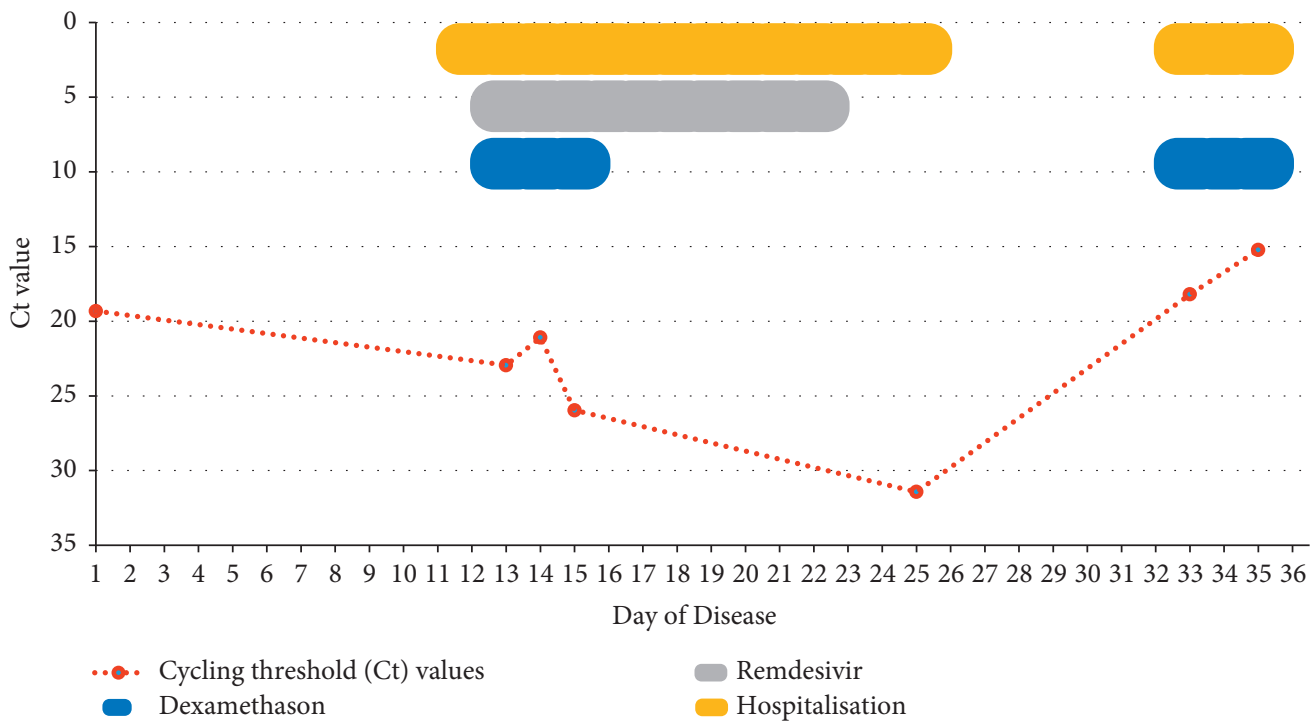

FIgURE 1: Timeline of cycling threshold $(\mathrm{Ct})$ values during disease course.

TABLE 2: Literature search of patients with COVID-19 and receiving immunosuppressive treatment including rituximab.

\begin{tabular}{|c|c|c|c|c|c|c|c|c|}
\hline Study & $\begin{array}{l}\text { Number of } \\
\text { patients }\end{array}$ & $\begin{array}{c}\text { Age } \\
\text { (years) }\end{array}$ & Gender & Underlying disease & $\begin{array}{c}\text { Repetitive positive } \\
\text { respiratory } \\
\text { sample by RT- } \\
\text { PCR }^{\mathrm{a}}\end{array}$ & $\begin{array}{l}\text { Duration of } \\
\text { symptoms } \\
\text { (days) }\end{array}$ & $\begin{array}{l}\text { Cumulative } \\
\text { hospital-days } \\
\text { (days) }\end{array}$ & Outcome \\
\hline $\begin{array}{l}\text { Avouac et al. } \\
{[2]}\end{array}$ & 63 & $59^{\mathrm{d}}$ & $\begin{array}{c}25 \\
\text { males } \\
38 \\
\text { females }\end{array}$ & $\begin{array}{c}\text { Inflammatory rheumatic } \\
\text { and musculoskeletal } \\
\text { diseases }\end{array}$ & NA & NA & $13^{\mathrm{d}}$ & $\begin{array}{c}13 / 63 \\
\text { died }\end{array}$ \\
\hline $\begin{array}{l}\text { Baang et al. } \\
\text { [3] }\end{array}$ & 1 & 60 & Male & Mantle cell lymphoma & Yes & NA & 6 & Survived \\
\hline $\begin{array}{l}\text { Sepulcri et al. } \\
\text { [4] }\end{array}$ & 1 & $60-70$ & Male & Mantle cell lymphoma & Yes & 271 & 268 & Died \\
\hline $\begin{array}{l}\text { Lancman } \\
\text { et al. [5] }\end{array}$ & 1 & 55 & Female & B-cell lymphoma & Yes & $55^{\mathrm{c}}$ & $40^{\mathrm{c}}$ & Survived \\
\hline Choi et al. [6] & 1 & 45 & Male & $\begin{array}{l}\text { Antiphospholipid } \\
\text { antibody syndrome }\end{array}$ & Yes & NA & 5 & Died \\
\hline $\begin{array}{l}\text { Friedman } \\
\text { and } \\
\text { Winthrop [7] } \\
\end{array}$ & 1 & 30 & Female & $\begin{array}{c}\text { Granulomatosis with } \\
\text { polyangiitis }\end{array}$ & Yes & Several weeks & NA & Survived \\
\hline Leipe et al. [8] & 1 & 63 & Male & $\begin{array}{c}\text { Granulomatosis with } \\
\text { polyangitis }\end{array}$ & $\mathrm{NA}^{\mathrm{b}}$ & 32 & 30 & Survived \\
\hline \multirow[t]{2}{*}{$\begin{array}{l}\text { Tepasse et al. } \\
{[9]}\end{array}$} & 2 & 65 & Male & $\begin{array}{l}\text { Cerebral diffuse large B- } \\
\text { cell lymphoma }\end{array}$ & $\mathrm{NA}^{\mathrm{b}}$ & 23 & 22 & Died \\
\hline & & 66 & Male & Mantle cell lymphoma & $\mathrm{NA}^{\mathrm{b}}$ & 30 & 26 & Died \\
\hline $\begin{array}{l}\text { Benucci et al. } \\
{[10]}\end{array}$ & 1 & 60 & Female & $\begin{array}{l}\text { Polymyositis and } \\
\text { Sjögren syndrome }\end{array}$ & Yes & 63 & 63 & Survived \\
\hline $\begin{array}{l}\text { Yasuda et al. } \\
\text { [11] }\end{array}$ & 1 & 61 & Female & Follicular lymphoma & Yes & $59^{c}$ & 59 & Survived \\
\hline $\begin{array}{l}\text { Guilpain et al. } \\
{[12]}\end{array}$ & 1 & 52 & Female & $\begin{array}{c}\text { Granulomatosis with } \\
\text { polyangiitis }\end{array}$ & Yes & 29 & 25 & Survived \\
\hline \multirow{2}{*}{$\begin{array}{l}\text { Schulze- } \\
\text { Koops et al. } \\
{[13]}\end{array}$} & \multirow[b]{2}{*}{2} & 71 & Male & Rheumatoid arthritis & No & 14 & 12 & Died \\
\hline & & 80 & Female & Rheumatoid arthritis & No & 17 & 17 & Died \\
\hline Kos et al. [14] & 1 & 72 & Male & $\begin{array}{c}\text { Nodal marginal zone } \\
\text { lymphoma }\end{array}$ & Yes & $31^{\mathrm{c}}$ & 24 & Survived \\
\hline
\end{tabular}


TABLE 2: Continued.

\begin{tabular}{|c|c|c|c|c|c|c|c|c|}
\hline Study & $\begin{array}{l}\text { Number of } \\
\text { patients }\end{array}$ & $\begin{array}{c}\text { Age } \\
\text { (years) }\end{array}$ & Gender & Underlying disease & $\begin{array}{l}\text { Repetitive positive } \\
\text { respiratory } \\
\text { sample by RT- } \\
\text { PCR }^{\mathrm{a}}\end{array}$ & $\begin{array}{l}\text { Duration of } \\
\text { symptoms } \\
\text { (days) }\end{array}$ & $\begin{array}{l}\text { Cumulative } \\
\text { hospital-days } \\
\text { (days) }\end{array}$ & Outcome \\
\hline $\begin{array}{l}\text { Fallet et al. } \\
{[15]}\end{array}$ & 1 & 77 & Female & $\begin{array}{c}\text { Granulomatosis with } \\
\text { polyangiitis and Sjögren } \\
\text { syndrome }\end{array}$ & No & $6^{c}$ & 6 & Survived \\
\hline $\begin{array}{l}\text { Wurm et al. } \\
{[16]}\end{array}$ & 1 & 59 & Female & Multiple sclerosis & Yes & 15 & 13 & Survived \\
\hline $\begin{array}{l}\text { Pascale } \\
\text { Daniel et al. } \\
{[17]}\end{array}$ & 1 & 55 & Male & $\begin{array}{l}\text { Granulomatosis with } \\
\text { polyangiitis }\end{array}$ & Yes & 29 & 22 & Survived \\
\hline
\end{tabular}

${ }^{\mathrm{a}}$ Tests drawn by nasopharyngeal swab, sputum, or bronchoalveolar lavage were considered. ${ }^{\mathrm{b}}$ The method of testing is not described. ${ }^{\mathrm{c}}$ Approximate values have been applied, because exact numbers were not documented. ${ }^{\mathrm{d}}$ Mean values.

CoV-2 infection despite vaccination because of the lack of antibody emergence and prolonged or relapsing disease courses have to be expected.

\section{Data Availability}

The data supporting the results are available, on request, from the authors.

\section{Consent}

Consent was obtained from the patient's husband.

\section{Conflicts of Interest}

The authors declare that there are no conflicts of interest.

\section{References}

[1] J. J. A. van Kampen, D. A. M. C. van de Vijver, P. L. A. Fraaij et al., "Duration and key determinants of infectious virus shedding in hospitalized patients with coronavirus disease2019 (COVID-19)," Nature Communications, vol. 12, no. 1, Article ID 267, 2021.

[2] J. Avouac, E. Drumez, E. Hachulla et al., "COVID-19 outcomes in patients with inflammatory rheumatic and musculoskeletal diseases treated with rituximab: a cohort study," The Lancet. Rheumatology, vol. 3, no. 6, pp. e419-e426, 2021.

[3] J. H. Baang, C. Smith, C. Mirabelli et al., "Prolonged severe acute respiratory syndrome coronavirus 2 replication in an immunocompromised patient," The Journal of Infectious Diseases, vol. 223, no. 1, pp. 23-27, 2021.

[4] C. Sepulcri, C. Dentone, M. Mikulska et al., "The longest persistence of viable SARS-CoV-2 with recurrence of viremia and relapsing symptomatic COVID-19 in an immunocompromised patient-a case study," medRxiv, vol. 28, no. 11, Article ID ofab217, 2021.

[5] G. Lancman, J. Mascarenhas, and M. Bar-Natan, "Severe COVID-19 virus reactivation following treatment for B cell acute lymphoblastic leukemia," Journal of Hematology \& Oncology, vol. 13, no. 1, Article ID 131, 2020.

[6] B. Choi, M. C. Choudhary, J. Regan et al., "Persistence and evolution of SARS-CoV-2 in an immunocompromised host," New England Journal of Medicine, vol. 383, no. 23, pp. 2291-2293, 2020.
[7] M. A. Friedman and K. L. Winthrop, "Second COVID-19 infection in a patient with granulomatosis with polyangiitis on rituximab," Annals of the Rheumatic Diseases, vol. 80, no. 8, pp. 1102-1104, 2021.

[8] J. Leipe, E. L. Wilke, M. P. Ebert, A. Teufel, and W. Reindl, "Long, relapsing, and atypical symptomatic course of COVID-19 in a B-cell-depleted patient after rituximab," Seminars in Arthritis and Rheumatism, vol. 50, no. 5, pp. 1087-1088, 2020.

[9] P. R. Tepasse, W. Hafezi, M. Lutz et al., "Persisting SARSCoV-2 viraemia after rituximab therapy: two cases with fatal outcome and a review of the literature," British Journal of Haematology, vol. 190, no. 2, pp. 185-188, 2020.

[10] M. Benucci, L. Quartuccio, F. Li Gobbi et al., "Persistence of rT-PCR-SARS-CoV-2 infection and delayed serological response, as a possible effect of rituximab according to the hypothesis of Schulze-Koops et al," Annals of the Rheumatic Diseases, 2020.

[11] H. Yasuda, Y. Tsukune, N. Watanabe et al., "Persistent COVID-19 pneumonia and failure to develop anti-SARSCoV-2 antibodies during rituximab maintenance therapy for follicular lymphoma," Clinical Lymphoma, Myeloma \& Leukemia, vol. 20, no. 11, pp. 774-776, 2020.

[12] P. Guilpain, C. Le Bihan, V. Foulongne et al., "Rituximab for granulomatosis with polyangiitis in the pandemic of covid-19: lessons from a case with severe pneumonia," Annals of the Rheumatic Diseases, vol. 80, no. 1, p. e10, 2021.

[13] H. Schulze-Koops, K. Krueger, I. Vallbracht, R. Hasseli, and A. Skapenko, "Increased risk for severe COVID-19 in patients with inflammatory rheumatic diseases treated with rituximab," Annals of the Rheumatic Diseases, vol. 80, no. 5, Article ID e67, 2020.

[14] I. Kos, B. Balensiefer, S. Roth et al., "Prolonged course of COVID-19-associated pneumonia in a B-cell depleted patient After rituximab," Frontiers in Oncology, vol. 10, Article ID $1578,2020$.

[15] B. Fallet, D. Kyburz, and U. A. Walker, "Mild course of COVID-19 and spontaneous virus clearance in a patient with depleted peripheral blood B cells due to rituximab treatment," Arthritis \& Rheumatology, vol. 72, no. 9, pp. 1581-1582, 2020.

[16] H. Wurm, K. Attfield, A. K. Iversen, R. Gold, L. Fugger, and A. Haghikia, "Recovery from COVID-19 in a B-cell-depleted multiple sclerosis patient," Multiple Sclerosis Journal, vol. 26, no. 10, pp. 1261-1264, 2020.

[17] P. Pascale Daniel, M. Marc Raad, R. Rami Waked, J. Jacques Choucair, M. Moussa Riachy, and F. Fady Haddad, "COVID- 
19 in a patient treated for granulomatosis with polyangiitis: persistent viral shedding with No cytokine storm," European journal of case reports in internal medicine, vol. 7, Article ID 1922, 2020.

[18] M. R. Tom and M. J. Mina, "To interpret the SARS-CoV-2 test, consider the cycle threshold value," Clinical Infectious Diseases, vol. 71, no. 16, pp. 2252-2254, 2020.

[19] J. J. Malin, I. Suárez, V. Priesner, G. Fätkenheuer, and J. Rybniker, "Remdesivir against COVID-19 and other viral diseases," Clinical Microbiology Reviews, vol. 34, no. 1, 2020.

[20] R. L. Gottlieb, C. E. Vaca, R. Paredes et al., "Early remdesivir to prevent progression to severe covid-19 in outpatients," New England Journal of Medicine, vol. 386, no. 4, pp. 305-315, 2022. 